\title{
The role of colorectal stent placement in the management of acute malignant obstruction
}

\author{
Hakan Yanar, M.D.,' ${ }^{1}$ Beyza Ozcinar, M.D.,' ${ }^{1}$ Fatih Yanar, M.D., ${ }^{1}$ \\ Emre Sivrikoz, M.D., ${ }^{1}$ Nergiz Dagoglu, M.D., ${ }^{2}$ Orhan Agcaoglu, M.D., ${ }^{1}$ \\ Kayihan Gunay, M.D., ${ }^{1}$ Recep Guloglu, M.D., ${ }^{1}$ Cemalettin Ertekin, M.D. ${ }^{1}$ \\ 1'Department of General Surgery, Istanbul University Istanbul Faculty of Medicine, Istanbul; \\ ${ }^{2}$ Department of Radiation Oncology, Istanbul University Istanbul Faculty of Medicine, Istanbul
}

\begin{abstract}
BACKGROUND: In recent decades, the use of colorectal stents for palliation or as a bridge to surgery in acute malignant colorectal obstruction has increased. We aimed to evaluate the technical and clinical efficacy, safety and clinical outcomes of endoscopic stenting for the relief of acute colorectal obstruction secondary to cancer.
\end{abstract}

METHODS: From March 2006 to December 2012, among 100 patients with acute malignant colorectal obstruction, stenting procedures were performed on 42 patients for relief of obstruction. Uncovered self-expanding metal stents (SEMS) were placed endoscopically under fluoroscopic guidance in all patients. Using the patient database, a review was conducted to determine the effectiveness of the procedure and the short- and long-term complications.

RESULTS: Stent placement was technically successful in $39 / 42$ (92.8\%) and clinically successful in $38 / 42$ (90.4\%) patients. Sixteen patients later underwent an elective surgical resection, and in 26 patients with metastatic disease or comorbidity, stent placement was palliative. Complications occurred in $10(23.8 \%)$ patients, and the most common was tenesmus $(n=3)$. Migration, bleeding, and rectosigmoid perforation occurred in two patients each. Stent obstruction due to fecal impaction was seen in one case.

CONCLUSION: Stent placement for colorectal obstruction is an effective and relatively safe procedure, with minor complications. It not only allows subsequent elective resection, but is also definitive for palliative treatment in patients with obstructive colorectal cancer.

Key words: Colorectal cancer; obstruction; self-expanding metal stents; stent.

\section{INTRODUCTION}

Acute mechanical intestinal obstruction secondary to colorectal cancer is one of the most common surgical emergencies, usually affecting the left colon. In patients with this condition, emergency surgery is associated with significantly increased morbidity and mortality, as well as ostomy rates. ${ }^{[1]}$ Since the introduction of colonic stenting, the endoscopic approach has been advocated as an alternative to traditional surgery for relieving acute colorectal obstruction, whether palliative or as a

\footnotetext{
Address for correspondence: Hakan Yanar, M.D.

İstanbul Üniversitesi İstanbul Tıp Fakültesi, Travma ve Acil Cerrahi Servisi, Genel Cerrahi Anabilim Dalı, Fatih, İstanbul, Turkey

Tel: +90 212 - 53। 1246 E-mail: htyanar@yahoo.com

Qucik Response Code

Ulus Travma Acil Cerr Derg

20I4;20(I):23-27

doi: $10.5505 /$ tjtes.2014.39596

Copyright 2014

TJTES
}

bridge to definitive surgery. Advantages of preoperative stent placement also include an elective laparoscopic resection of the tumor as well as the ability to perform a full colonoscopy preoperatively to exclude any synchronous lesions.

Utilization of self-expanding metal stents (SEMS) in the colon was first reported in 1991, ${ }^{[2]}$ and one year later, Spinelli and colleagues $^{[3]}$ reported the placement of a modified GianturcoRosch stent to relieve an acute colonic obstruction secondary to cancer. Although endoscopic alleviation of colorectal obstruction has been used increasingly in recent years, it has not yet become a standard treatment option.

In the present study, we aimed to evaluate the technical and clinical efficacy, safety and clinical outcomes of SEMS for the relief of acute colorectal obstruction secondary to cancer.

\section{MATERIALS AND METHODS}

From March 2006 to December 20I2, 100 patients with a mean age of 66 years (range, 32-88 years) admitted due to acute colorectal obstruction secondary to cancer were treated 
in our emergency surgery service. Acute colorectal obstruction was diagnosed as follows: absence of any flatus or bowel movements in the preceding 24 hours, abdominal distention, fecaloid vomiting, and the presence of dilated colonic loops on abdominal radiograph. All patients underwent a routine workup employed for acute mechanical intestinal obstruction (physical exam, blood tests, abdominal X-ray, and computed tomography $[C T]$ scan or magnetic resonance imaging $[M R I])$. The rectal cancers were grouped into upper $(8-15 \mathrm{~cm})$ and lower $(0-7 \mathrm{~cm})$ rectum based on the distance from the anal verge. Colonoscopy with biopsy was performed after hemodynamic stabilization of the patient. In all patients, uncovered self-expanding, through-the-scope metal stents were inserted endoscopically under endoscopic and fluoroscopic monitoring within 24 hours of admission.

Prior to the stent placement, the colon or rectum was cleansed per enema below the stricture. All stenting procedures were performed in the left lateral decubitus position. All patients were premedicated with 2-4 mg intravenous (IV) midazolam and 25-50 mg pethidine hydrochloride before the procedure. To estimate the length, proximal extension, and diameter of the stricture, a water-soluble contrast agent was injected. Under fluoroscopic guidance, a SEMS (Changzhou Zhiye Medical ${ }^{\circledR}$ China), $6-12 \mathrm{~cm}$ in length and $22 \mathrm{~mm}$ in diameter, was inserted through the colonoscope. All patients underwent abdominal radiographs to verify the position of the stent as well as to rule out free air. In cases of free peritoneal air, emergency laparotomy was undertaken.

After staging, all patients were evaluated with total colonoscopy passing through the stent to rule out any synchronous lesions. Technical success was defined as successful placement and deployment of the SEMS. Clinical success was considered as colonic decompression within $\mathbf{4 8}$ hours without additional endoscopic or surgical intervention following a technically successful SEMS insertion. Antibiotic prophylaxis was applied either with cefuroxime axetil plus metronidazole or ampicillinsulbactam, because inflation of the colon with air during the procedure risks promoting perforation and/or bacteremia. After obtaining adequate decompression of the colon (in cases

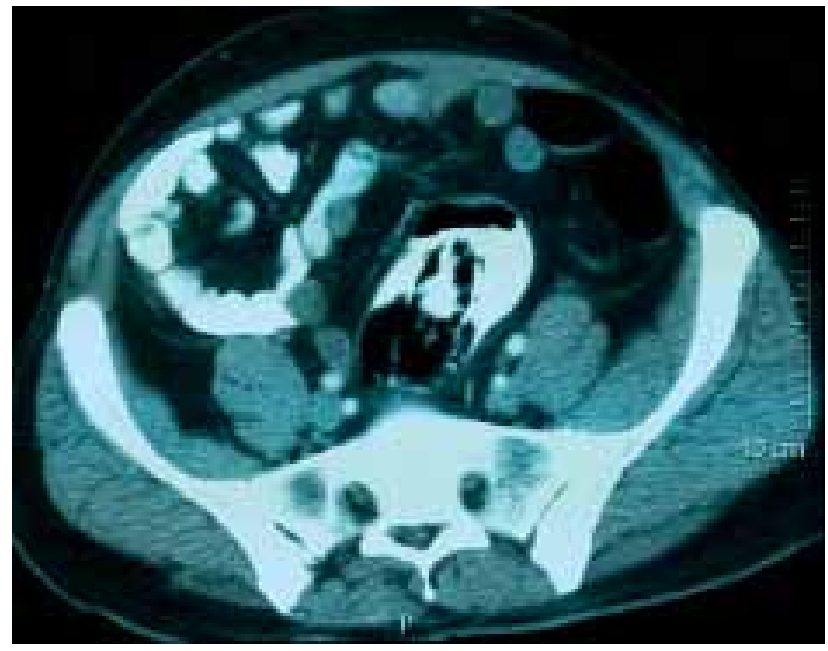

Figure 1. CT scan of a stent placed across a malignant recto-sigmoid structure.

when staging necessitated a neoadjuvant treatment, following chemoradiotherapy), patients underwent elective open or laparoscopic resection.

A retrospective review of the prospectively compiled patient database was conducted to determine the effectiveness of the procedure, as well as short- and long-term complications. The complications and success rates of the two study groups were compared using Pearson's chi-square or Fisher's exact test as appropriate for categorical variables. Statistical significance was set as $p<0.05$. The Statistical Package for the Social Sciences (SPSS) VI6.0 was used for the statistical analyses.

\section{RESULTS}

Stent placement was attempted in 42 of 100 patients. Twenty-six patients underwent SEMS insertion for palliation and 16 patients as a bridging to surgery.

The location of obstruction was observed as the left colon in 2 patients, sigmoid colon in 3 patients, recto-sigmoid junction in 9 patients, upper rectum in 16 patients, and lower rectum

Table I. Complications and success rate according to the indication for stenting

\begin{tabular}{lccc}
\hline & $\begin{array}{c}\text { Palliation group } \\
(\mathbf{n}=\mathbf{2 6})\end{array}$ & $\begin{array}{c}\text { Bridging to surgery group } \\
(\mathbf{n}=16)\end{array}$ & $\mathbf{p}$ \\
\hline Technical success & 24 & 15 & 0.858 \\
Clinical success & 24 & 14 & 0.606 \\
Tenesmus & 2 & $\mathrm{I}$ & 1.000 \\
Migration & 2 & - & 0.255 \\
Perforation & $\mathrm{I}$ & $\mathrm{I}$ & 0.722 \\
Bleeding & 2 & - & 0.255 \\
Re-obstruction & - & $\mathrm{I}$ & 0.197 \\
\hline
\end{tabular}



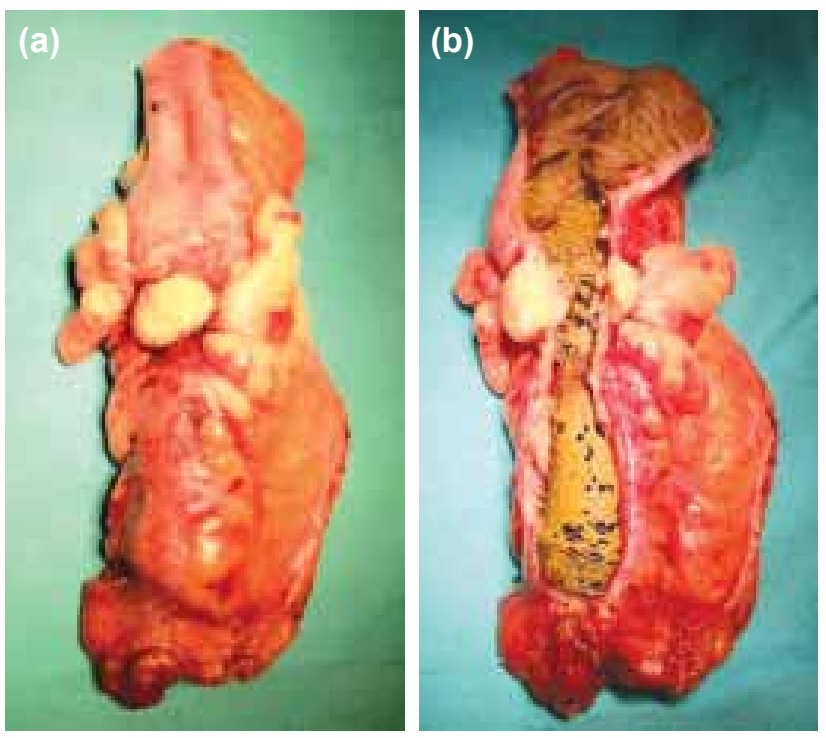

Figure 2. (a, b) Sigmoid colectomy specimen showing an endoluminal metallic stent when resected en bloc with the sigmoid tumor.

in 12 patients. The median follow-up period was 28 months (range, 3-58 months) and the median length of hospital stay was 4 days (range, 2-12 days). Technical success of SEMS placement was achieved in $39 / 42(92.8 \%)$ and clinical success in $38 / 42$ (90.4\%) patients (Fig. I). There were no significant differences in complications and success rates when the palliation group was compared with the bridging-to-surgery group $(p>0.05)$ (Table I).

Through-the-stent colonoscopy revealed right colon and transverse colon polyps in 2 patients, who subsequently underwent an endoscopic polypectomy. Sixteen patients, for whom bridging to surgery proved successful later, underwent an elective surgical resection (Table 2) (Fig. 2), while for 26 patients who had metastatic disease or comorbidity, stent placement was palliative. Tenesmus was the most common complication, noted in $3(7 \%)$ patients, and resolved within 10 days (8-12 days). Distal stent migration occurred in 2 of $42(4 \%)$ cases in whom a technically successful insertion had been achieved. Both of the migrations occurred within the same day of stent placement (I patient with extrinsic compression and I patient with distal rectal cancer). Stent replacement was unsuccessful, and these 2 patients underwent sigmoid loop colostomy for re-obstruction. Rectal bleeding, observed in 2 of 42 patients (4\%), stopped spontaneously, and neither blood transfusion nor any other treatment was required.

Insertion-related immediate perforation occurred in 2 patients at the recto-sigmoid junction, whereas no delayed perforation was observed. These patients underwent subtotal colectomy with ileorectal anastomosis. Stent obstruction due to fecal impaction was encountered in I case.

\section{DISCUSSION}

Approximately $30 \%$ of patients with primary colorectal cancer present with subtotal or complete bowel obstruction, which may lead from nausea and vomiting to bowel rupture and finally to death should the condition remain untreated. ${ }^{[4,5]} \mathrm{A}$ number of surgical techniques are available: intraoperative lavage with resection of the involved colonic segment followed by primary anastomosis; subtotal colectomy followed by primary anastomosis; decompressive colostomy followed by resection; and resection of the involved colonic segment followed by end colostomy (Hartmann's operation), ultimately requiring another operation to constitute the gastrointestinal continuity. However, permanent ostomy creation undertaken under emergency conditions is associated with high morbidity rates. The alteration of an acute mechanical colonic obstruction requiring prompt surgical intervention into a semi-elective decompressed state that allows bowel preparation and one-stage definitive oncologic colorectal resection renders this initial endoscopic approach most appealing.

Self-expanding metal stents (SEMS) are placed for several indications in patients with obstructive colorectal malignancies. Advantages of preoperative stent placement include laparoscopic resection of the tumor as well as the ability to perform an elective preoperative colonoscopy to exclude synchronous lesions. On the other hand, following relief of the obstruction with SEMS, the patient can be adequately staged and offered neoadjuvant chemoradiotherapy -whenever indicated- and eventually undergo an elective or semi-elective one-stage colorectal resection. Additionally, stents can be used for palliation of inoperable obstructive colorectal malignancies or extrinsic compression.

Table 2. Type of surgical procedure after bridging to surgery

\begin{tabular}{llc}
\hline Diagnosis & Type of surgical procedure & n \\
\hline Low rectal tumor & Laparoscopic low anterior resection & 9 \\
Low rectal tumor & Low anterior resection* & 4 \\
Sigmoid tumor & Laparoscopic sigmoid resection & 2 \\
Sigmoid tumor & Sigmoid resection & I \\
\hline * After neoadjuvant chemoradiotherapy.
\end{tabular}


The feasibility, safety, and efficacy of SEMS were evaluated by various retrospective studies. Technical and clinical success rates of SEMS insertion are reported as $94 \%$ and $91 \%$, respectively, with negligible SEMS-related mortality. ${ }^{[6-9]}$ According to these studies, colonic stent placement was found to be a relatively safe technique with a high success rate. In the present study, technical and clinical success rates of SEMS insertion were comparable to those reported in the literature, at $92.8 \%$ and $90.4 \%$, respectively.

Colorectal perforation is one of the most common and feared complications of SEMS placement. The greatest risk of perforation is in the recto-sigmoid area, especially at the rectosigmoid junction. A higher probability of perforation appears to confront patients who have had balloon pre-dilation; thus, prior stricture dilation is not recommended. ${ }^{[6-9]}$ Bevacizumab has also been reported to put patients at significant risk for perforation. Stenting is best avoided, if possible, in patients who are candidates for bevacizumab therapy. ${ }^{[10]}$ In this study, even though balloon dilation was performed on four patients before stent placement, two perforations occurred. These patients had a sharp angulation at the perforation site. Following these events, we abandoned the practice of performing balloon dilation prior to stent insertion.

Stent migrations tend to occur with size-mismatched stents (either too narrow or short in relation to the obstructing lesion) and in the presence of a non-obstructive stricture or of tumor shrinkage following neoadjuvant therapy. In a systematic review evaluating the efficacy and safety of colorectal stents, migration was found to be notably more frequent after laser debulking or chemotherapy, as well as in patients with strictures of benign etiology. ${ }^{[7]}$ In this study, distal stent migration was reported in two (5\%) patients, one with extrinsic compression and the other with a lower rectum tumor (0-7 $\mathrm{cm}$ ), and both occurred within 24 hours. In our experience, stenting should be avoided in patients with a distal rectal tumor up to $2 \mathrm{~cm}$ from the anal canal.

Extrinsic compression from pelvic malignancies and lymphadenopathy causing obstruction may also be palliated with stents. ${ }^{\left[{ }^{[I]}\right.}$ However, stenting of extracolonic malignancy is clinically less successful (20\%) when compared to colorectal malignancy. Complication rates (33.3\%) are markedly increased, and surgical diversion is required more frequently. ${ }^{[12]}$ In the present series, SEMS was used in one patient for palliation of gastric cancer metastasis to the pelvis. In this patient, stent migration occurred and stent replacement was unsuccessful. Due to the relatively small sample size of this study, we were unable to clarify the difference in overall complication rates between intrinsic and extrinsic lesions.

There are a number of reported absolute contraindications to colorectal stenting: (I) clinical or radiological evidence of perforation, and (2) distal rectal cancer $(0-5 \mathrm{~cm}$ from anal verge), where stenting is likely to cause intense anal pain and/ or fecal incontinence. Relative contraindications include challenging colorectal anatomy (i.e. long strictures, tortuous colonic segments) and colonic ischemia. ${ }^{[13-15]}$

Laparoscopy is generally contraindicated in the presence of bowel obstruction since a distended bowel precludes a safe access to the abdominal cavity as well as manipulation of the bowel segments. Conversion of an emergent colonic resection into an elective one permits bowel preparation and may potentially avoid an ostomy. Following successful endoscopic stenting of acute colorectal obstruction secondary to cancer, laparoscopic resection may be performed safely with wellknown short-term advantages. An endoluminal stent per se does not necessarily preclude a laparoscopic approach. ${ }^{[16-20]}$ In this study, laparoscopic resection was technically feasible and comparable to elective colorectal operations, and the presence of a colorectal stent did not affect the laparoscopic approach; II patients underwent a successful laparoscopic colorectal resection. SEMS may also provide long-term symptom relief for benign colorectal strictures secondary to diverticular disease, radiotherapy, inflammation, or Crohn's disease, should these patients be deemed medically unfit to undergo a major abdominal operation. ${ }^{[21-23]}$ Benign stricture was not evaluated in the present study.

In conclusion, stenting of acute mechanical colonic obstruction is an effective option for patients presenting with obstructive colorectal cancer, in which decompression is required to perform an elective one-stage oncologic surgical resection. This approach may also offer palliation for patients who are not candidates for operative intervention, and it is associated with a lower mortality, shorter hospital stay, and decreased stoma creation.

\section{Conflict of interest: None declared.}

\section{REFERENCES}

1. Ansaloni L, Andersson RE, Bazzoli F, Catena F, Cennamo V, Di Saverio $\mathrm{S}$, et al. Guidelenines in the management of obstructing cancer of the left colon: consensus conference of the world society of emergency surgery (WSES) and peritoneum and surgery $(\mathrm{PnS})$ society. World J Emerg Surg 2010;5:29. CrossRef

2. Dohmoto M. New method endoscopic implantation of rectal stent in palliative treatment of malignant stenosis. Endoscopia Digestiva 1991;3:1507-12.

3. Spinelli P, Dal Fante M, Mancini A. Self-expanding mesh stent for endoscopic palliation of rectal obstructing tumors: a preliminary report. Surg Endosc 1992;6:72-4. CrossRef

4. Mauro MA, Koehler RE, Baron TH. Advances in gastrointestinal intervention: the treatment of gastroduodenal and colorectal obstructions with metallic stents. Radiology 2000;215:659-69. CrossRef

5. Soto S, López-Rosés L, González-Ramírez A, Lancho A, Santos A, Olivencia P. Endoscopic treatment of acute colorectal obstruction with self-expandable metallic stents: experience in a community hospital. Surg Endosc 2006;20:1072-6. CrossRef 
6. Small AJ, Coelho-Prabhu N, Baron TH. Endoscopic placement of selfexpandable metal stents for malignant colonic obstruction: long-term outcomes and complication factors. Gastrointest Endosc 2010;71:560-72.

7. Khot UP, Lang AW, Murali K, Parker MC. Systematic review of the efficacy and safety of colorectal stents. Br J Surg 2002;89:1096-102. CrossRef

8. Sebastian S, Johnston S, Geoghegan T, Torreggiani W, Buckley M. Pooled analysis of the efficacy and safety of self-expanding metal stenting in malignant colorectal obstruction. Am J Gastroenterol 2004;99:2051-7.

9. Dionigi G, Villa F, Rovera F, Boni L, Carrafiello G, Annoni M, et al. Colonic stenting for malignant disease: review of literature. Surg Oncol 2007;16 Suppl 1:153-5. CrossRef

10. Cennamo V, Fuccio L, Mutri V, Minardi ME, Eusebi LH, Ceroni L, et al. Does stent placement for advanced colon cancer increase the risk of perforation during bevacizumab-based therapy? Clin Gastroenterol Hepatol 2009;7:1174-6. CrossRef

11. Shin SJ, Kim TI, Kim BC, Lee YC, Song SY, Kim WH. Clinical application of self-expandable metallic stent for treatment of colorectal obstruction caused by extrinsic invasive tumors. Dis Colon Rectum 2008;51:578-83. CrossRef

12. Keswani RN, Azar RR, Edmundowicz SA, Zhang Q, Ammar T, Banerjee $B$, et al. Stenting for malignant colonic obstruction: a comparison of efficacy and complications in colonic versus extracolonic malignancy. Gastrointest Endosc 2009;69:675-80. CrossRef

13. Song HY, Kim JH, Shin JH, Kim HC, Yu CS, Kim JC, et al. A dualdesign expandable colorectal stent for malignant colorectal obstruction: results of a multicenter study. Endoscopy 2007;39:448-54. CrossRef

14. Harris GJ, Senagore AJ, Lavery IC, Fazio VW. The management of neoplastic colorectal obstruction with colonic endolumenal stenting devices. Am J Surg 2001;181:499-506. CrossRef
15. Baron TH, Kozarek RA. Endoscopic stenting of colonic tumours. Best Pract Res Clin Gastroenterol 2004;18:209-29. CrossRef

16. Stipa F, Pigazzi A, Bascone B, Cimitan A, Villotti G, Burza A, et al. Management of obstructive colorectal cancer with endoscopic stenting followed by single-stage surgery: open or laparoscopic resection? Surg Endosc 2008;22:1477-81. CrossRef

17. Balagué C, Targarona EM, Sainz S, Montero O, Bendahat G, Kobus C, et al. Minimally invasive treatment for obstructive tumors of the left colon: endoluminal self-expanding metal stent and laparoscopic colectomy. Preliminary results. Dig Surg 2004;21:282-6. CrossRef

18. Morino M, Bertello A, Garbarini A, Rozzio G, Repici A. Malignant colonic obstruction managed by endoscopic stent decompression followed by laparoscopic resections. Surg Endosc 2002;16:1483-7. CrossRef

19. Dulucq JL, Wintringer P, Beyssac R, Barberis C, Talbi P, Mahajna A. One-stage laparoscopic colorectal resection after placement of self-expanding metallic stents for colorectal obstruction: a prospective study. Dig Dis Sci 2006;51:2365-71. CrossRef

20. Law WL, Choi HK, Lee YM, Chu KW. Laparoscopic colectomy for obstructing sigmoid cancer with prior insertion of an expandable metallic stent. Surg Laparosc Endosc Percutan Tech 2004;14:29-32. CrossRef

21. Small AJ, Young-Fadok TM, Baron TH. Expandable metal stent placement for benign colorectal obstruction: outcomes for 23 cases. Surg Endosc 2008;22:454-62. CrossRef

22. Baron TH. Colonic stenting: technique, technology, and outcomes for malignant and benign disease. Gastrointest Endosc Clin N Am 2005;15:757-71. CrossRef

23. Suzuki N, Saunders BP, Thomas-Gibson S, Akle C, Marshall M, Halligan S. Colorectal stenting for malignant and benign disease: outcomes in colorectal stenting. Dis Colon Rectum 2004;47:1201-7. CrossRef

\section{KLINIK ÇALIŞMA - ÖZET}

\section{Akut malign kalın bağırsak tıkanmalarında kolorektal stent uygulamasının rolü \\ Dr. Hakan Yanar, ${ }^{1}$ Dr. Beyza Özçınar, ${ }^{1}$ Dr. Fatih Yanar, ${ }^{1}$ Dr. Emre Sivrikoz, ${ }^{1}$ Dr. Nergiz Dağoğlu, ${ }^{2}$ \\ Dr. Orhan Ağcaoğlu, ${ }^{1}$ Dr. Kayıhan Günay, ${ }^{1}$ Dr. Recep Güloğlu, ${ }^{1}$ Dr. Cemalettin Ertekin ${ }^{1}$}

1'stanbul Üniversitesi Tıp Fakültesi, Genel Cerrahi Anabilim Dalı, İstanbul;

${ }^{2}$ İstanbul Üniversitesi Tıp Fakültesi, Radyasyon Onkolojisi Anabilim Dalı, İstanbul

AMAÇ: Son yıllarda akut malign kalın bağırsak tıkanmalarında gerek palyasyon gerek cerrahi öncesi dekompresyon amaçlı kolorektal stentlerin kullanımı artış göstermektedir. Bu çalışmada, kansere bağı akut kolorektal tıkanmalarda endoskopik stent uygulamasının teknik ve klinik açıdan etkinliği, güvenilirliği ve klinik sonuçlarını değerlendirmeyi amaçladık.

GEREÇ VE YÖNTEM: Mart 2006-Aralık 2012 tarihleri arasında acil cerrahi kliniğimizde akut malign kalın bağırsak tıkanması tanısıyla tedavi edilen 100 hastanın 42'sine stentleme uygulandı. Tüm hastalara kaplı olmayan genişleyen metal stentler endoskopik yöntemle fluoroskopi eşliğinde yerleştirildi. Hasta veritabanı kullanılarak yöntemin etkinliği ve komplikasyonlar geriye dönük olarak değerlendirildi.

BULGULAR: Stentleme işlemi teknik açıdan 39/42 (\%92.8), klinik açıdan 38/42 (\%90.4) hastada başarıyla uygulandı. Bunlardan 16 hastaya elektif cerrahi rezeksiyon uygulandı, diğer 26 hastada metastatik tümör veya yandaş hastalıklar nedeniyle işlem palyatif olarak kabul edildi. On (\%23.8) hastada komplikasyon gelişti, en sık tenesmus $(n=3)$ izlendi. Stent migrasyonu, kanama ve rekto-sigmoid kolon perforasyonu ikişer hastada izlendi. Bir olguda gaita sıkışmasına bağı stent tıkanması meydana geldi.

TARTIŞMA: Malignite kaynaklı akut kolorektal tıkanmalarda stentleme efektif ve göreceli olarak güvenli bir işlem olup, hafif dereceli komplikasyolara neden olur. Obstrüktif kolorektal kanser hastalarında elektif rezeksiyona olanak sağlamakta, ayrıca cerrahi tedaviye uygun olmayan olgularda palyasyon amaçlı kullanılabilmektedir.

Anahtar sözcükler: Kolorektal kanser; tıkanıklık; kendiliğinden genişleyen metal stent; stent.

Ulus Travma Acil Cerr Derg 2014;20(I):23-27 doi: 10.5505/tjtes.20।4.39596 